\title{
Mycobacterium paratuberculosis DNA not detected in Crohn's disease tissue by fluorescent polymerase chain reaction
}

\author{
D S Rowbotham, N P Mapstone, L K Trejdosiewicz, P D Howdle, P Quirke
}

\begin{abstract}
The role of mycobacteria in the aetiology of Crohn's disease has been a contentious subject for many years. Mycobacterium paratuberculosis is known to cause a chronic granulomatous enteritis in animals (Johne's disease) and has been implicated as a possible infectious cause of Crohn's disease. However this fastidious organism is only rarely detected by conventional microbiological techniques. This study used oligonucleotide primers to the species-specific $M$ paratuberculosis IS900 DNA insertion element and the polymerase chain reaction to amplify any $M$ paratuberculosis DNA from intestinal tissue DNA extracts. One oligonucleotide primer was fluorochrome-labelled and the presence of fluorescent amplified product was determined using an automated DNA sequencer with a computerised gel-scanning laser. This method was shown capable of detecting 1-2 mycobacterial genomes. Intestinal tissue samples were obtained from 68 patients with histologically confirmed Crohn's disease, 49 patients with histologically confirmed ulcerative colitis, and 26 non-inflammatory bowel disease controls. In no case was $M$ paratuberculosis detected in any of the inflammatory bowel disease tissue samples and only one non-inflammatory bowel disease case was positive. These results do not support the hypothesis that $M$ paratuberculosis has an aetiological role in Crohn's disease.

(Gut 1995; 37: 660-667)
\end{abstract}

Keywords: Crohn's disease, Mycobacterium paratuberculosis DNA, polymerase chain reaction.

Division of Medicine, St James's University Hospital, Leeds D S Rowbotham L K Trejdosiewicz P D Howdle

Division of Pathology, Leeds General Infirmary, University of Leeds, Leeds N P Mapstone P Quirke

Correspondence to: Dr D S Rowbotham, The Liver Unit, King's College Hospital, Denmark Hill, London SE5 9RS

Accepted for publication 11 April 1995

The aetiology of Crohn's disease remains unclear. The similarities between this condition and intestinal tuberculosis, however, led to the original and persisting hypothesis that Crohn's disease could also have a mycobacterial origin. ${ }^{2}$ In recent years much attention has been focused on one particular mycobacterial species, namely Mycobacterium paratuberculosis. This organism is known to be the cause of Johne's disease, a chronic granulomatous enteritis of ruminants ${ }^{34}$ and of chronic enteritides in other animals, including primates. ${ }^{5} M$ paratuberculosis has been cultured from a small number of patients with Crohn's disease. ${ }^{6-11} \mathrm{~A}$ possible aetiological role, however, has been difficult to define because of the slow growth rate and fastidious nature of this organism in vitro ${ }^{12}$ and also because of its very close similarity with Mycobacterium avium, a species ubiquitous in the environment ${ }^{13} 14$ and therefore in the human gut. This makes accurate identification by conventional microbiological methods very difficult.

The discovery of IS900, a repeating DNA insertion element in the $M$ paratuberculosis genome specific to that organism ${ }^{9} 1516$ was an important step forward. Utilisation of the polymerase chain reaction (PCR) to amplify fragments of IS 900 permits rapid and accurate detection of $M$ paratuberculosis DNA from tissue without the need for laborious and time consuming culture. ${ }^{17} 18$ However, recent published reports are conflicting. Reports of positive detection of $M$ paratuberculosis DNA from intestinal tissue of patients with Crohn's disease ${ }^{19-22}$ were not substantiated by reports from other centres that describe negative results using PCR. ${ }^{23} 24$ Thus, a mycobacterial aetiology for Crohn's disease remains a contentious hypothesis.

Recent advances in technology combining the use of fluorochrome-labelled oligonucleotide primers for PCR, along with laser detection of the amplified fluorescent DNA products, permits more sensitive identification of positive samples. This obviates the need for laborious techniques such as Southern blotting and the handling of radioactive probes. Therefore, utilising such technology, this study was undertaken to apply these new techniques to DNA extracted from intestinal tissue so as to assess the prevalence of $M$ paratuberculosis in the human gut from patients with Crohn's disease, ulcerative colitis, and also from noninflammatory bowel disease controls.

\section{Methods}

PATIENTS AND SAMPLES

Samples of intestinal tissue were obtained from patients undergoing either colonoscopy or surgical resection at The General Infirmary or St James's University Hospital, Leeds. Included in this study were 68 patients with Crohn's disease, 49 patients with ulcerative colitis, and 26 non-inflammatory bowel disease controls, comprising rectal bleeding (five cases), diarrhoea (four cases), changed bowel habit (four cases), anaemia (four cases), irritable bowel syndrome (three cases), colonic polyps (two cases), ascites (one case), coeliac 
Characteristics of patients

\begin{tabular}{|c|c|c|c|}
\hline & $\begin{array}{l}\text { Crohn's } \\
\text { disease }\end{array}$ & $\begin{array}{l}\text { Ulcerative } \\
\text { colitis }\end{array}$ & Controls \\
\hline $\begin{array}{l}\text { Number } \\
\text { Age }\end{array}$ & 68 & 49 & 26 \\
\hline $\begin{array}{l}\text { Mean }(y) \\
\text { Range }\end{array}$ & $\begin{array}{l}46 \cdot 3 \\
15-80\end{array}$ & $\begin{array}{l}43 \cdot 8 \\
14-78\end{array}$ & $\begin{array}{l}52 \cdot 8 \\
26-80\end{array}$ \\
\hline Sex ratio (male:female) & $21: 47$ & $25: 24$ & $11: 15$ \\
\hline Colon & 59 & 49 & 26 \\
\hline Small intestine & 9 & 0 & 0 \\
\hline $\begin{array}{l}\text { Immunosuppression } \\
\text { (local/oral/parenteral) }\end{array}$ & 61 & 43 & 4 \\
\hline
\end{tabular}

In two cases there was both small and large bowel material available for PCR from the same patient. These were analysed as separate specimens. The other small intestinal specimens were obtained from patients in whom there was also evidence of colonic disease but no colonic tissue could be collected.

disease (one case), systemic lupus erythematosus (one case), and pseudomembranous colitis (one case). The diagnoses of Crohn's disease and ulcerative colitis were confirmed using standard clinical, radiological, and histological criteria. Tissue samples were obtained from both diseased and macroscopically normal intestine, where possible, in all patients. The Table shows the characteristics of subjects in each disease group.

Colonoscopic biopsy specimens were immediately placed into dry, sterile $2 \mathrm{ml}$ microcentrifuge tubes. Resected tissue specimens were wrapped in clean aluminium foil and placed in a new container. All samples were labelled and snap frozen by immersion in liquid nitrogen and stored at $-70^{\circ} \mathrm{C}$ until required.

\section{DNA EXTRACTION}

\section{Patient tissue samples}

Samples were thawed and placed in $2 \mathrm{ml}$ microcentrifuge tubes for digestion (approximately 1 gram of tissue per tube). The digestion buffer comprised $100 \mathrm{mM} \mathrm{NaCl}, 25 \mathrm{mM}$ EDTA (disodium salt), $0.5 \%$ w:v sodium dodecyl sulphate (SDS) and $10 \mathrm{mM}$ TRIS$\mathrm{HCl}(\mathrm{pH} \mathrm{8.0)}$ ). Some $200 \mu \mathrm{l}$ of digestion buffer containing Proteinase K (Gibco BRL, Paisley, Scotland) at a final concentration of $2 \mathrm{mg} / \mathrm{ml}$ was used per tube. Samples were incubated at $37^{\circ} \mathrm{C}$ for 60 hours with constant agitation. At the end of the incubation, $200 \mu \mathrm{l}$ of lysis buffer, (10 mM EDTA, $10 \mathrm{mM}$ TRIS- $\mathrm{HCl}$ (pH $8 \cdot 0$ ) and $0.1 \%$ w:v polyethylene sorbitan monolaureate (TWEEN 20)), containing chicken egg lysosyme (Boehringer Mannheim, Lewes, Sussex, UK) at $4 \mathrm{mg} / \mathrm{ml}$ was added and the tubes mixed at $37^{\circ} \mathrm{C}$ for a further two hours. After digestion, $67 \quad \mu l$ of $5 \mathrm{M} \mathrm{NaCl}$ and $50 \mu \mathrm{l}$ of $0.7 \mathrm{M} \mathrm{NaCl}$ containing $10 \% \mathrm{w}: \mathrm{v}$ hexadecyltrimethylammonium bromide (CTAB) were added to each tube. The water used in all the experiments was 'Molecular Biology Grade' (Merck; BDH Laboratory Supplies, Poole, UK).

Following incubation at $65^{\circ} \mathrm{C}$ for 10 minutes, samples were subjected to two cycles of chloroform/isoamylalcohol extraction (24:1 v:v) and a single extraction with TRIS buffersaturated phenol:chloroform:isoamylalcohol (25:24:1 v:v; Amresco, Solon, Ohio). The DNA was then recovered by precipitation with
$1 \mathrm{ml}$ of ice cold absolute ethanol (analytical grade) and $100 \mu \mathrm{l}$ of $3 \mathrm{M}$ sodium acetate $(\mathrm{pH}$ $5 \cdot 2$ ) at $-20^{\circ} \mathrm{C}$ overnight. DNA was pelleted by microcentrifugation for 10 minutes. Excess salt was redissolved and removed with $1 \mathrm{ml}$ of ice cold $70 \%$ ethanol, and the tubes were dried in a desiccator for two hours. Finally, the DNA was resuspended in $100 \mu l$ of water and incubated, with tumbling, at $37^{\circ} \mathrm{C}$ for 48 hours to ensure complete dissolution. Extracted DNA samples were stored in the dark at $+4^{\circ} \mathrm{C}$ and used for PCR experiments within seven days.

One blank tube with no intestinal tissue was included with each batch of samples undergoing DNA extraction to act as a control for the extraction procedure.

Mycobacterium paratuberculosis organisms To confirm successful extraction of DNA from $M$ paratuberculosis, aliquots of Mycobacterium avium ss paratuberculosis (strain 'Map') were used, grown from stock cultures kindly donated by Professor J Ivanyi, London, UK. These organisms were cultured in Kirchner's medium (Southern Group Laboratory, Corby, UK) enriched with mycobactin (kindly supplied by Professor C Ratledge, Hull University, UK). One hundred $\mu 1$ aliquots of $M$ paratuberculosis in Kirchner's medium were placed into sterile $2 \mathrm{ml}$ microcentrifuge tubes. Half of the tubes were then snap frozen in liquid nitrogen and kept at $-70^{\circ} \mathrm{C}$ for two hours before thawing to reproduce the conditions experienced by the intestinal tissue samples. Both fresh and prefrozen $M$ paratuberculosis organisms were processed using the DNA extraction techniques described above.

\section{Fohne's disease tissue}

Paraffin wax embedded intestinal tissue from a goat, confirmed to have Johne's disease by histology, Ziehl Nielsen staining, and culture, was kindly provided by Dr David Piercy, Central Veterinary Laboratory, Weybridge, Surrey, UK. After dewaxing, the intestinal tissue was processed using the DNA extraction procedure as above.

\section{'Linda' strain $\mathrm{M}$ paratuberculosis positive control DNA}

$M$ paratuberculosis of the 'Linda' strain was kindly donated by Dr D Y Graham, Houston, Texas. This strain was cultured from the intestinal tissue of a young patient with Crohn's disease. ${ }^{67}$ The mycobacteria were provided in the form of solid culture on a Lowenstein-Jensen slope. The organisms were harvested and DNA extracted enzymatically by the process described above. This DNA was used as the positive control in all experiments. The concentration of $M$ paratuberculosis DNA was assessed by fluorimetry using $0 \cdot 1 \mu \mathrm{g} / \mathrm{ml}$ Hoechst 33258 (Polysciences, Warrington, PA) in TNE buffer, (10 $\mathrm{mM}$ TRIS/ $/ \mathrm{HCl}, 1$ $\mathrm{mM}$ EDTA, $100 \mathrm{mM} \mathrm{NaCl}$ at $\mathrm{pH} 8.0$ ), on a TKO 100 Fluorometer (Hoefer Scientific 


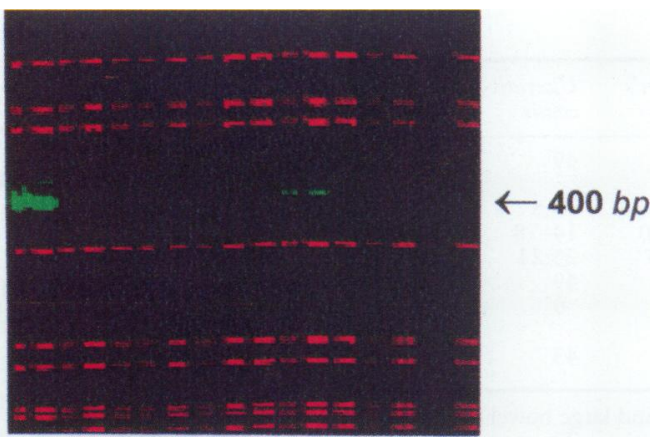

1234567891011121314151617

Figure 1: Amplification and detection of fluorescent M paratuberculosis DNA by IS900 PCR. Gel image showing green fluorescent 400 base pair (bp) amplification product in lanes 1 and 2 (Fohne's disease tissue DNA, at concentrations of $50 \%$ and $100 \%$ ), lane 11 ('Linda' $\mathrm{M}$ paratuberculosis $D N A$ ) and lane 12 ('Map' $\mathrm{M}$ paratuberculosis $D N A$ ). The gel lanes are: 1 and 2 fohne's disease tissue; $3 \mathrm{M}$ marinum; $4 \mathrm{M}$ gordonae; 5 $M$ tuberculosis; $6 \mathrm{M}$ bovis; $7 \mathrm{M}$ avium; $8 \mathrm{M}$ terrae; 9 $M$ reynolds; $10 \mathrm{M}$ malm; $11 \mathrm{M}$ paratuberculosis

('Linda'); $12 \mathrm{M}$ paratuberculosis ('Map'); 13 BCG; 14 $M$ kansasii; 15 and 16 blank DNA extraction controls; 17 no DNA PCR negative control. Genescan 2500 Rox

Standards are seen as multiple red bands in each gel lane permitting accurate sizing of fluorescent products to a single base pair in length.

Instruments, Newcastle under Lyme, Staffs, UK). Stock 'Linda' DNA was then serially diluted 10 -fold with water to provide a range of concentrations from 1 to $1 \times 10^{-9}$ of $M$ paratuberculosis DNA.

\section{'Spiking' experiments}

A set of experiments was designed to exclude any inhibition of either DNA extraction or subsequent PCR amplification of $M$ paratuberculosis DNA by human tissue. Normal intestinal tissue from a non-inflammatory bowel disease patient (irritable bowel syndrome) was taken and divided into sterile microcentrifuge tubes. One tube was capped and used as a negative

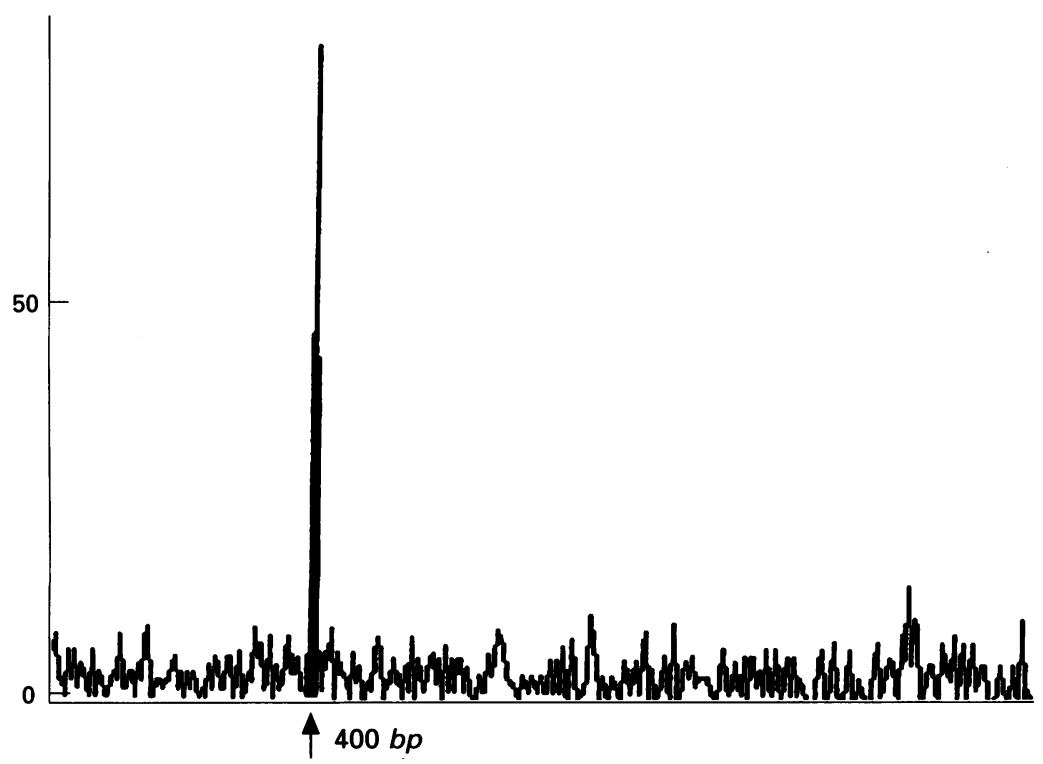

Figure 2: Detection of fluorescent M paratuberculosis DNA by IS900 PCR. Cross sectional electrophoretogram of an individual gel lane showing 400 base pair (bp) fluorescent peak indicating positive amplification and detection of $10^{-7}$ dilution of Linda $M$ paratuberculosis DNA. This equates to the detection, by $P C R$, of $\leqslant 10 \mathrm{fg}$ of $M$ paratuberculosis $D N A$, equivalent to 1-2 mycobacterial genomes. control for this experiment. To the other tubes were added $50 \mu \mathrm{l}$ aliquots of mycobacterial suspensions from stock cultures (donated by Professor J Ivanyi , London) in Kirchner's medium. The species used were $M$ paratuberculosis (strain 'Map'), its closest relative $M$ avium (strain 'MaB2') and BCG-P (Pasteur). All tubes were then snap frozen in liquid nitrogen, thawed, and processed using the DNA extraction process described above.

\section{Comparison of DNA extraction techniques}

The DNA extraction method described above was developed after experience with many techniques and represents the most efficient DNA extraction process in our hands. In view of positive results published during the course of this study, however, ${ }^{19}$ experiments were set up to compare directly our DNA extraction method with the method used in the published study. Resected specimens from five patients with Crohn's disease stored at $-70^{\circ} \mathrm{C}$ were thawed and quartered, using a new sterile scalpel blade for each specimen, and placed into sterile microcentrifuge tubes. Two tubes from each patient were taken for DNA extraction using the method exactly as described by Sanderson et al ${ }^{19}$ and two tubes were extracted using the method described above. Before commencing extraction, one tube from each pair was 'spiked' with an aliquot of stock $M$ paratuberculosis ('Map') suspension. Samples were then put through the respective DNA extraction techniques and the precipitated DNA redissolved in water or TEN buffer as appropriate. DNA extracted from spiked samples was serially diluted 10 -fold, giving a range from 1 to $1 \times 10^{-6}$ before use in the PCR assay.

\section{PCR ASSAY}

The 5' portion of IS 900 chosen for amplification produced DNA fragments of 400 base pairs in length. The pair of oligonucleotide primers used were synthesised using a 391 DNA Synthesiser (Applied Biosystems, Warrington, UK). The sequences of the primers used were 5'-X-GTT CGG GGC CGT CGC TTA GG-3' (primer 1) and 5'GAG GTC GAT CGC CCA CGT GA-3' (primer 2). Primer 1 was prelabelled with a fluorescein-derived dye, Joe (Applied Biosystems), in the position represented by $\mathrm{X}$ in the base sequence description above.

The PCR was performed in $50 \mu l$ total volumes in sterile $500 \mu \mathrm{l}$ microcentrifuge tubes. Fifty pmol of the standard ammonia based primer 2 was dried down in each tube using a desiccator. PCR reaction mixtures were made up using the following reagents: $5 \mu \mathrm{l} \mathrm{PCR}$ buffer (100 mM TRIS/HCl (pH 9.0), $500 \mathrm{mM}$ $\mathrm{KCl}, 1 \%$ Triton $\times 100$, and $0 \cdot 1 \%$ gelatin made up as $10 \times$ stock), $7.5 \mu \mathrm{MgCl} \mathrm{Mgl}_{2}(1.5$ $\mathrm{mM}$ ), $8 \mu \mathrm{l}$ deoxynucleotide triphosphates (dNTP; $100 \mu \mathrm{M}$; Boehringer Mannheimer), 20 pmol fluorescent primer 1 , one unit of Taq DNA polymerase, and water up to $49 \mu \mathrm{l}$. Two drops of mineral oil (Sigma Chemical, Poole, 


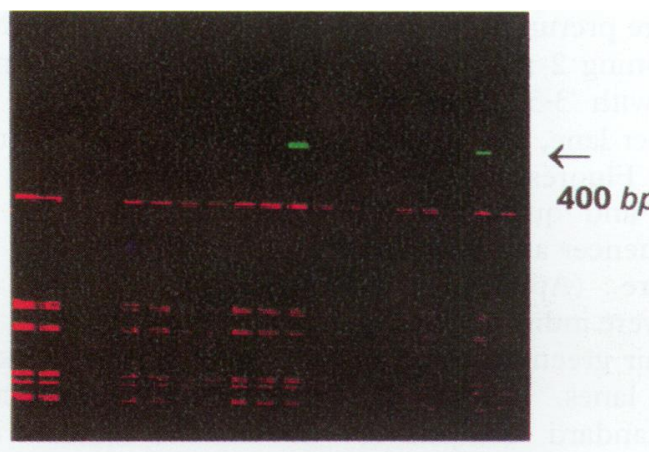

$12345678910 \underline{11} 121314151617 \underline{18} 19$
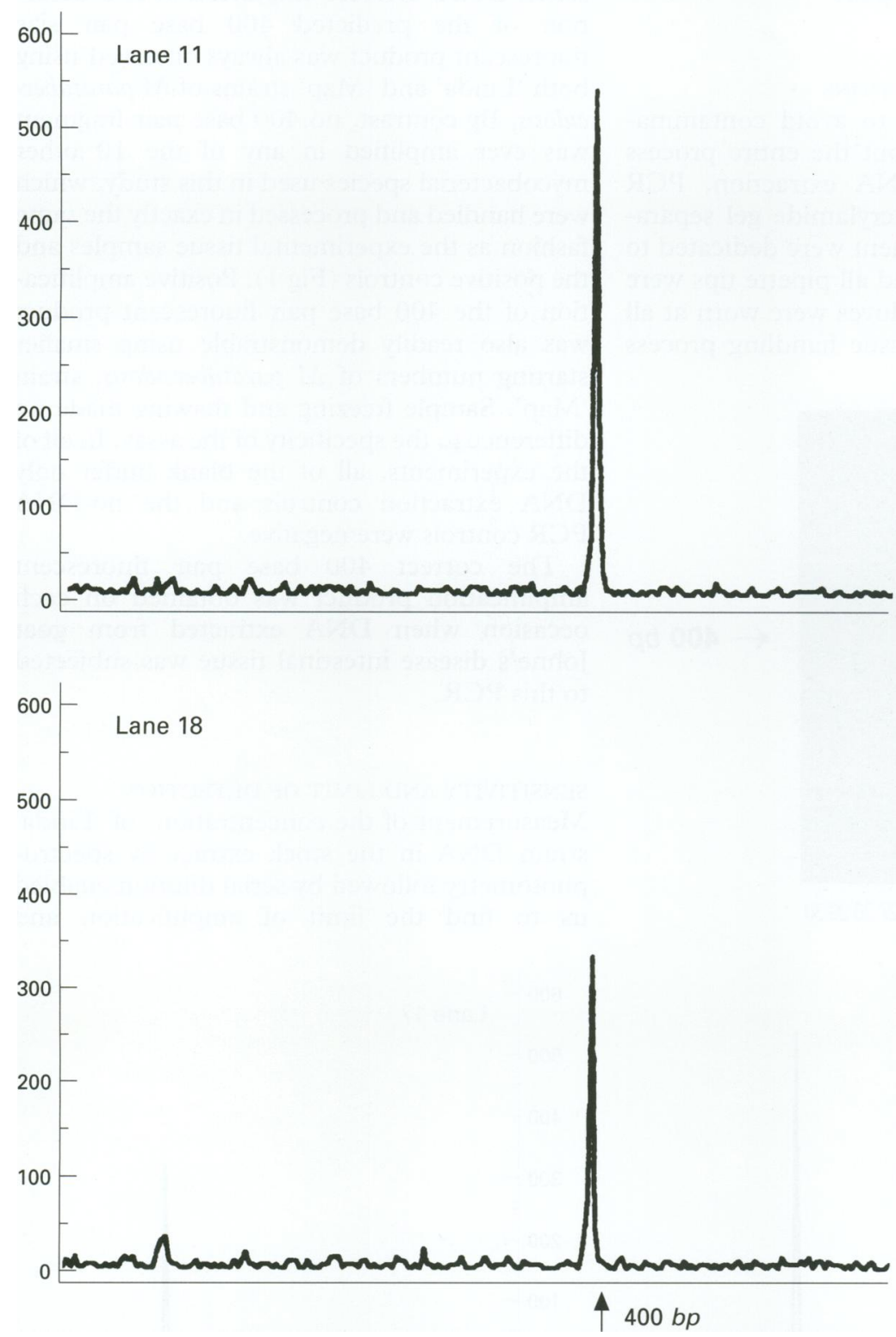

Figure 3: Amplification and detection of fluorescent M paratuberculosis DNA by IS900 $P C R$. Gel image and cross sectional electrophoretograms showing detection of $\mathrm{M}$ paratuberculosis DNA in one non-inflammatory bowel disease control patient (lane 18) with irritable bowel syndrome. Sizing of this PCR product green fluorescent peak confirms it to be 400 base pairs in length, identical to the positive control 'Linda' $M$

paratuberculosis DNA in lanes 11 and 12. Gel lanes are: $1 \mathrm{M}$ marinum; $2 \mathrm{M}$

gordonae; $3 \mathrm{M}$ tuberculosis; $4 \mathrm{M}$ bovis; $5 \mathrm{M}$ avium; $6 \mathrm{M}$ terrae; $7 \mathrm{M}$ reynolds; $8 \mathrm{M}$ malm; 9 BCG; $10 \mathrm{M}$ kansasii; 11 and 12 'Linda' $M$ paratuberculosis $D N A$ dilutions $10^{-6}$ and $10^{-7}$; 13 blank DNA extraction control; 14 to 20 intestinal tissue DNA extracts from study patients. controls were added first, followed by the patient samples and specificity controls. To minimise any possibility of cross contamination, all completed tubes were capped immediately after addition of their sample DNA and moved to another part of the laboratory before the 'Linda' $M$ paratuberculosis DNA was added to the sensitivity control tubes.

The PCR was carried out on a PTC-100 Programmable Thermal Controller (MJ Research, Watertown, MA) and comprised 30 cycles of a three step program involving denaturation at $95^{\circ} \mathrm{C}$ for one minute, annealing at $58^{\circ} \mathrm{C}$ for one minutes, and extension at $72^{\circ} \mathrm{C}$ for two minutes.

\section{PCR controls}

For sensitivity controls, DNA from cultured $M$ paratuberculosis strain 'Linda' was extracted enzymatically as above. Ten-fold serial dilutions of the extracted DNA were used to determine the sensitivity of the PCR. 'Linda' DNA was always added to the PCR positive control tubes in increasing concentrations to prevent any cross tube contamination, a potential source of misleading results for the PCR sensitivity. After initial formal identification of the limits of detection of the assay, each PCR run used $M$ paratuberculosis DNA in three dilutions $\left(10^{-6}, 10^{-7}\right.$, and $\left.10^{-8}\right)$ to include the previously determined level of sensitivity and one 10-fold dilution either side of this to ensure no drifting of the efficiency of the reaction. Thirty cycles of PCR amplification was found to give optimum results.

The specificity of each PCR run was checked by using a panel of 10 other related mycobacterial species. These included $M$ marinum, $M$ gordonae, $M$ tuberculosis, $M$ bovis, $M$ terrae, $M$ reynolds, $M$ malm, $M$ kansasii, BCG-P, and the most closely related species $M$ avium. These organisms were subjected to the identical DNA extraction process as the positive control 'Linda' $M$ paratuberculosis organisms and all of the study patient tissue samples.

\section{Negative controls}

Each PCR run included negative control tubes in the form of DNA tissue extraction controls comprising sterile water taken through identical processing to the intestinal tissue, and negative PCR controls containing no extracted DNA.

\section{DNA gel separations}

Fluorescent PCR products were separated on $6 \%$ polyacrylamide slab gels in a Model 373A Automated DNA Sequencer (Applied Biosystems) following the manufacturer's protocols. Sample PCR products for separation were prepared by mixing $0.6 \mu \mathrm{l}$ 'Genescan 2500 Rox' Standard (Applied Biosystems), $0.5 \mu l$ loading buffer (Applied Biosystems), $3 \mu \mathrm{l}$ formamide, and $1 \mu \mathrm{l}$ of the fluorescent PCR DNA products. The final DNA mix was denatured at $95^{\circ} \mathrm{C}$ for five minutes before
UK) were added to prevent evaporation. Finally, $1 \mu$ l of specimen DNA was added to make up final volumes of $50 \mu \mathrm{l}$. Blank DNA extraction controls and no-DNA negative PCR 
cooling to $+4^{\circ} \mathrm{C}$. Gels were prerun in $89 \mathrm{mM}$ TRIS-borate buffer containing $2 \mathrm{mM}$ EDTA for 30 minutes, loaded with $3.5 \mu l$ of the denatured PCR product per lane, and run for 14 hours at 30 watts. Fluorescent DNA products were identified and quantified by the Automated DNA Sequencer and analysed using Genescan software (Applied Biosystems). Positive results were indicated by the presence of a 400 base pair green fluorescent band in any of the gel lanes. Use of the Genescan 2500 Rox Standard comprising multiple red bands of known lengths permitted sizing of any fluorescent PCR products to an accuracy of a single base pair.

\section{CONTAMINATION PRECAUTIONS}

Painstaking precautions to avoid contamination were used throughout the entire process of tissue collection, DNA extraction, PCR amplification, and polyacrylamide gel separation. Rooms and equipment were dedicated to individual procedures and all pipette tips were sterile and single-use. Gloves were worn at all times throughout the tissue handling process

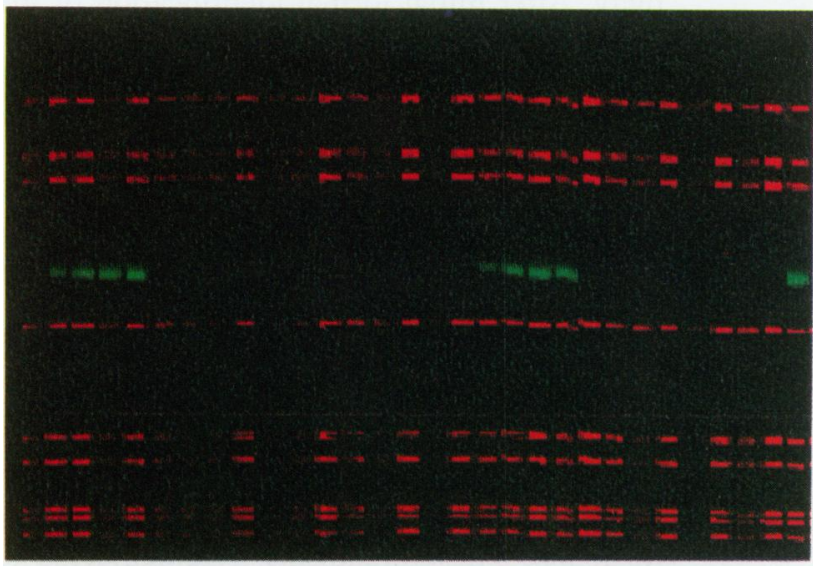

$\leftarrow 400 b p$

$12345678910111213141516 \underline{17} 18192021222324252627282930$

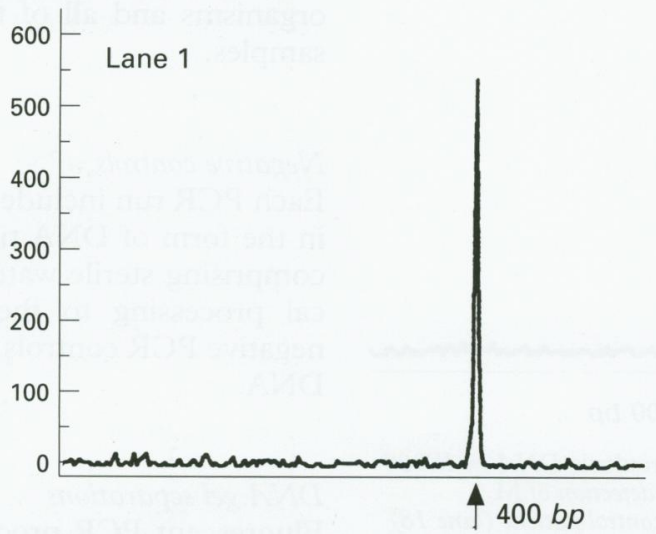

with frequent glove changes. Our laboratories handle very large numbers of PCR reactions every month (more than 4000) and contamination of PCR products is unusual using current protocols.

\section{Results}

\section{SPECIFICITY OF PCR DETECTION}

Using the DNA extraction procedure described above and a standard three step PCR program with 30 cycles of amplification, we were able to reliably and reproducibly detect $M$ paratuberculosis DNA. Correct amplification and detection of the predicted 400 base pair size fluorescent product was always observed using both 'Linda' and 'Map' strains of $M$ paratuberculosis. By contrast, no 400 base pair fragment was ever amplified in any of the 10 other mycobacterial species used in this study, which were handled and processed in exactly the same fashion as the experimental tissue samples and the positive controls (Fig 1). Positive amplification of the 400 base pair fluorescent product was also readily demonstrable using smaller starting numbers of $M$ paratuberculosis, strain 'Map'. Sample freezing and thawing made no difference to the specificity of the assay. In all of the experiments, all of the blank buffer only DNA extraction controls and the no-DNA PCR controls were negative.

The correct 400 base pair fluorescent amplification product was obtained on each occasion when DNA extracted from goat Johne's disease intestinal tissue was subjected to this PCR.

\section{SENSITIVITY AND LIMIT OF DETECTION}

Measurement of the concentration of 'Linda' strain DNA in the stock extract by spectrophotometry followed by serial dilution enabled us to find the limit of amplification and

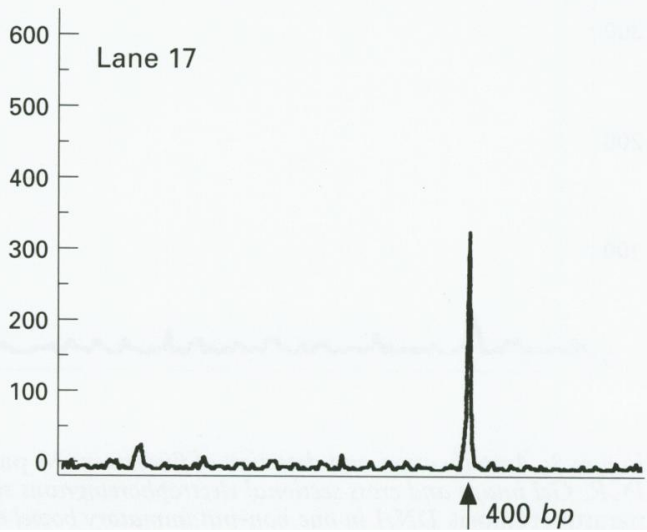

Figure 4: Amplification and detection of fluorescent $M$ paratuberculosis DNA by IS900 PCR. Gel image showing direct comparison of DNA extraction techniques between our method and that described by Sanderson et al. ${ }^{19}$ Crohn's disease tissue 'spiked' with aliquots of M paratuberculosis ('Map') underwent DNA extraction using both methods. DNA was then serially diluted before use in the IS900 PCR. The techniques are shown to be comparable in their ability to extract, amplify, and detect M paratuberculosis DNA. Examination of individual lane cross sectional electrophoretograms show positive amplification of a 400 base pair green fluorescent product from 'spiked' Crohn's disease tissue down to a dilution of $10^{-4}$ with both DNA extraction methods. None of the non-spiked Crohn's disease tissue samples extracted by either method were positive. Gel lanes are: 1 to 5 10-fold dilutions of 'spiked' Crohn's disease tissue DNA extracted using our method $\left(10^{-4}, 10^{-3}, 10^{-2}, 10^{-1}\right.$, and neat); 6 non-spiked Crohn's disease tissue DNA (our method); $7 \mathrm{M}$ marinum; $8 \mathrm{M}$ gordonae; $9 \mathrm{M}$ tuberculosis; $10 \mathrm{M}$ bovis; $11 \mathrm{M}$ avium; $12 \mathrm{M}$ terrae; $13 \mathrm{M}$ reynolds; $14 \mathrm{M}$ malm; $15 B C G$; $16 \mathrm{M}$ kansasii; 17 to 21 10-fold dilutions of 'spiked' Crohn's disease tissue DNA extracted by the method of Sanderson et al $\left(10^{-4}, 10^{-3}, 10^{-2}, 10^{-1}\right.$, and neat); 22 non-spiked Crohn's disease tissue DNA (Sanderson et al);23 to 29 intestinal tissue DNA extracts from study patients; 30 'Linda' $\mathrm{M}$ paratuberculosis positive control. 
detection of our fluorescent PCR (Fig 2). Using the Genescan system, the limit of positive detection occurred at a dilution of $10^{-7}$ of the stock 'Linda' DNA, which corresponds to the amplification of $\leqslant 10 \mathrm{fg}$ of $M$ paratuberculosis DNA, equivalent to 1-2 mycobacterial genomes. As only $1 \%$ of the total extracted DNA was used for PCR amplification and detection, the overall limit of detection of our techniques is estimated at less than 200 bacilli per intestinal tissue specimen. Sensitivity was not compromised by freeze-thawing.

\section{DETECTION OF M PARATUBERCULOSIS DNA IN INTESTINAL TISSUES}

Despite the confirmed sensitivity, specificity, and reproducibility of the techniques, none of the intestinal samples from patients with Crohn's disease or ulcerative colitis showed amplification of $M$ paratuberculosis DNA. Positive amplification of $M$ paratuberculosis DNA was detected in only one of the noninflammatory bowel disease control patients. This was from a 55 year old female subject undergoing colonoscopy with a final diagnosis of irritable bowel syndrome (Fig 3).

'SPIKING' AND DNA EXTRACTION EXPERIMENTS To include inhibition of amplification by PCR, control non-inflammatory bowel disease tissue was 'spiked' with intact mycobacteria. Positive detection of a 400 base pair fluorescent amplification product was obtained from spiking with 'Map' $M$ paratuberculosis but not from spiking with the other mycobacterial species used. The internal tissue-only control was also negative.

Direct comparison of DNA extraction techniques between out method and that described by Sanderson et al ${ }^{19}$ showed them to be comparable in their ability to extract and amplify $M$ paratuberculosis DNA (Fig 4). Examination of the gel image and cross sectional electrophoretograms of individual lanes showed positive amplification of a 400 base pair product, using both methods, down to a dilution of $10^{-4}$ of the DNA extracted from the spiked Crohn's disease tissue. None of the non-spiked Crohn's disease tissue samples were positive.

\section{Discussion}

The results described here throw doubt on the hypothesis that $M$ paratuberculosis plays a part in the aetiology of Crohn's disease. Our own early work ${ }^{25}$ using standard oligonucleotide primers, ethidium bromide agarose gels, and Southern blotting with internal radiolabelled probing produced results that were hampered by false positives. These were shown to arise because of inter-mycobacterial species cross reactions. Strenuous efforts to eradicate such cross reactions were made and our PCR assay method was refined such that we could achieve excellent and reproducible specificity. Using a fluorescent PCR method with automated analysis has also helped eliminate artefacts that can arise in gel blotting methods. Using this approach, we have shown that our IS 900 PCR assay is specific for $M$ paratuberculosis against a panel of 10 other mycobacteria including the very closely related species, $M$ avium. ${ }^{26}$ The sensitivity of the assay was shown by the reliable and reproducible amplification and detection of $\leqslant 10 \mathrm{fg}$ of $M$ paratuberculosis DNA, corresponding to less than 200 organisms per tissue sample used in the experiment.

A potential problem in the detection of mycobacterial DNA is that mycobacterial walls are very robust, thereby potentially hampering DNA extraction. Although we initially used Johne's disease goat intestine to demonstrate effective DNA extraction, the very high density of $M$ paratuberculosis in this tissue makes it a poor model. Therefore, in an attempt to establish a better model of the numbers of mycobacteria that might be present in human gut, we 'spiked' intestinal specimens with small aliquots of $M$ paratuberculosis suspension before DNA extraction. The high mechanical forces required to disrupt aggregates of $M$ paratuberculosis in suspension would have risked liberating mycobacterial DNA before enzymatic extraction and thereby created an inaccurate impression of the efficiency of our DNA extraction process. This precluded accurate qualification of actual numbers of mycobacteria detectable on 'spiking'. Nevertheless, our experiments showed amplification of DNA from even very small numbers of $M$ paratuberculosis (strain 'Map'), with no ill effects from freezing and rethawing. Thus, we conclude that our extraction process is efficient at liberating genomic mycobacterial DNA.

As our negative results directly contradict the study reporting positive amplification of $M$ paratuberculosis in $65 \%$ of Crohn's disease specimens, ${ }^{19}$ we felt that it was mandatory to compare the DNA extraction techniques. However, we could detect little difference in sensitivity and hence in extraction efficiency in serial dilutions of DNA from Crohn's disease tissue 'spiked' with $M$ paratuberculosis and in each comparison experiment the results were nearly identical. Moreover, we compared our own extraction protocol with that of Sanderson et al ${ }^{19}$ on five unspiked Crohn's disease patient samples from both small intestine and colon, and from sites of varying disease activity involving quiescent disease through to severe active inflammation. Assuming an incidence of $65 \% M$ paratuberculosis positives in Crohn's disease tissue, then the probability of all five of our unspiked Crohn's disease specimens being negative was estimated at approximately $0.0053 \%$. However, all five were indeed negative using both DNA extraction procedures.

To exclude any inhibition in the assay, experiments were conducted using tissue samples spiked with whole mycobacterial suspension before the DNA extraction procedure. Positive PCR amplification of the correct 400 base pair product was obtained after spiking with $M$ paratuberculosis but not with other mycobacterial species. This experiment excluded inhibition during the DNA extraction process as well as inhibition during PCR 
amplification as the spiking was done with whole mycobacteria rather than free mycobacterial $\mathrm{DNA}^{19}$. Unspiked tissue samples were uniformly negative.

There are clearly important differences between our findings and those of Sanderson et $a l^{19}$ and indeed reports from other centres. ${ }^{20-22}$ There have also been reports, however, stating that $M$ paratuberculosis DNA cannot be found in human gut tissue despite utilising similar techniques to those reports above. ${ }^{23} 24 \mathrm{~A}$ number of reasons for these discrepancies may be considered. For instance, disease activity of the sampled tissue may be important. Higher concentrations of $M$ paratuberculosis may accumulate in and around inflamed tissue as a primary cause of the inflammation or by passive carriage by infiltrating inflammatory cells. Alternatively, increased inflammation leading to ulceration could result in shedding of cells and mycobacteria into the lumen of the bowel, thus making detection in tissue less likely. Results may also be influenced by the presence of granulomata in the tissue samples. ${ }^{20}$ To try and encompass these arguments we have used bowel tissue from a range of anatomical sites in the small intestine and colon, and from a broad range of disease activity (as judged both clinically and histologically). To eliminate bias we have used samples obtained from two separate sources: operative resections and colonoscopic biopsy specimens. Both of these sampling methods included tissue with a broad range of disease activity and although we did not specifically microdissect out granulomata, we have tested both granulomatous and non-granulomatous Crohn's disease tissue. The tissue was also collected from two separate hospitals. We found no difference in rates of detection of $M$ paratuberculosis between sites of sampling within the bowel, the presence of granulomata, the degree of tissue inflammatory activity, surgical versus endoscopy specimens or in the hospital attended by the patients.

The type of material used for study may be important. Paraffin wax embedded tissue, in our experience, requires more cycles of amplification to achieve the same sensitivity as fresh tissue, thereby increasing the risks of false positive results. We have used fresh snap-frozen tissue samples with fewer PCR cycles as this approach is less likely to produce false positives and in our hands is more sensitive. The ages of patients sampled may have a bearing on results as positive cultured isolates of $M$ paratuberculosis have generally been obtained from younger Crohn's disease patients. ${ }^{67}$ However, as we have tested patients ranging from teenagers to octogenarians with uniformly negative results, we do not consider that age is a factor in the likelihood of amplifying and detecting $M$ paratuberculosis DNA.

Perhaps the most probable reason for the discrepancies relates to differences in technique and the possibility of artefactual positives. Laboratory contamination is a well recognised problem when using $\mathrm{PCR}^{27} 28$ and requires the most rigorous steps for its elimination. Contamination artefact may be expected to occur, however, as positives randomly distributed between the three clinical groups of Crohn's disease, ulcerative colitis and non-inflammatory bowel disease controls which does not seem to be the case in previous reports. These findings, however, could be explained if separate experimental PCR runs were performed using tissue samples from a single diagnostic group. Contamination artefacts may then appear as unexpected positives in mainly one diagnostic group. Other technical problems can occur due to excessive numbers of PCR amplification cycles and insufficient stringency using blotting methods for detection of PCR products. In fact, we attribute our own earlier preliminary positive findings ${ }^{25}$ to just such artefacts. The ease with which artefactual or false positives can be generated in some PCR detection methods underlines the fundamental importance of reliable, accurate, and reproducible PCR specificity controls.

Thus, our findings lead us to conclude that $M$ paratuberculosis is not a factor in the aetiopathogenesis of Crohn's disease. For future progress in this field, the exchange of tissue between collaborative centres for double blind testing could potentially provide the most stringent test of the mycobacterial hypothesis of Crohn's disease.

This work was supported by a grant from the National Association for Colitis and Crohn's disease to whom we express Association for Colitis and Crohn's disease to whom we express Crohn's in Childhood Research Appeal, We are indebted to all of our colleagues who helped by providing tissue suitable for analyour colleagues who helped by providing tissue suitable for analy-
sis. We also wish to thank Professor J Ivanyi for gifts of mycobacsis. We also wish to thank Professor J Ivanyi for gifts of mycobac-
terial cultures. The invaluable advice of Fraser Lewis in all aspects terial cultures. The invaluable advice of Fraser Lewis in all aspects o Deborah Cross and Debbie Dockey for technical assistance. The preliminary results of this work were previously outlined in abstract form in Gut 1993; 34: A228.

1 Dalziel TK. Chronic interstitial enteritis. $B M \mathcal{F}$ 1913; ii: $1068-70$.

2 Crohn BB, Ginzburg L, Oppenheimer GD. Regional ileitis,

a pathologic and clinical entity. $¥ A M A$ 1932; 99: 1323-9.
3 Johne HA, Frothingham L. Ein Eigenthuemlicher Fall von Tuberkulose beim Rind. Dtsch Z Tiermedicin Pathol 1895 21: 438-54.

4 Chiodini RJ, Van Kruiningen HJ, Merkal RS. Ruminant paratuberculosis (Johne's disease): the current status and future prospects. Cornell Vet 1984; 74: 218-62.

5 McClure HM, Chiodini RJ, Anderson DC, Swenson RB, Thayer WR, Coutu JA. Mycobacterium paratuberculosis infection in a colony of stumptail macaques (Macaca arctoides). F Infect Dis 1987; 155: 1011-9.

6 Chiodini RJ, Van Kruiningen HJ, Thayer WR, Merkal RS, Coutu JA. Possible role of mycobacteria in inflammatory bowel disease. I. An unclassified Mycobacterium species isolated from patients with Crohn's disease. Dig Dis Sci isolated from patient

7 Chiodini RJ, Van Kruiningen HJ, Merkal RS, Thayer WR Coutu JA. Characteristics of an unclassified mycobacterium species isolated from patients with Crohn's disease. $\mathcal{F}$ Clin Microbiol 1984; 20: 966-71.

8 Coloe P, Wilks CR, Lightfoot D, Tosolini FA. Isolation of Mycobacterium paratuberculosis in Crohn's disease. Australian fournal of Microbiology 1986; 7: 188A.

9 McFadden JJ, Butcher PD, Chiodini R, Hermon-Taylor J. Crohn's disease-isolated mycobacteria are identical to Mycobacterium paratuberculosis, as determined by DNA probes that distinguish between mycobacterial species. f Clin Microbiol 1987; 25: 796-801.

10 Haagsma J, Mulder CJJ, Eger A, Bruins J, Ketel RJ, Tytgat GNJ. Mycobacterium species isolated from patients with Crohn's disease. In: MacDermott RP, ed. Inflammatory bowel disease: current status and future approach. bowel disease: current status and future

11 Gitnick G, Collins J, Beaman B, Brooks D, Arthur M, Imaeda $T$, et al. Preliminary report on isolation of mycobacteria from patients with Crohn's disease. Dig Dis Sci 1989; 34: 925-32.

12 Chiodini RJ. Crohn's disease and the mycobacterioses: a review and comparison of two disease entities. Clin Microbiol Rev 1989; 2: 90-117.

13 Kazda J. The principals of the ecology of mycobacteria. In: Ratledge C, Stanford J, eds. The biology of mycobacteria. London: Academic Press, 1983: 323-41. 
14 Portaels F, Larsson L, Smeets P. Isolation of mycobacteria from healthy persons' stools. Int $\mathcal{F}$ Leprosy 1988; 56: 468-71.

15 Green EP, Tizard MLV, Moss MT, Thompson J, Winterbourne DJ, McFadden J, et al. Sequence and characteristics of IS900, an insertion element identified in a human Crohn's disease isolate of Mycobacterium paratuberculosis. Nucleic Acids Res 1989; 17: 9063-73.

16 Hermon-Taylor J, Moss MT, Tizard MLV, Malik Z, Sanderson JD. Molecular biology of Crohn's disease mycobacteria. Ballières Clin Gastroenterol 1990; 4: 23-42.

17 Moss T, Green EP, Tizard MLV, Malik Z, Hermon-Taylor J. Specific detection of Mycobacterium paratuberculosis by DNA hybridisation with a fragment of the insertion element IS900. Gut 1991; 32: 395-8.

18 Vary PH, Anderson PR, Green E, Hermon-Taylor J, McFadden JJ. Use of highly specific DNA probes and the polymerase chain reaction to detect Mycobacterium paratuberculosis in Johne's disease. F Clin Microbiol 1990; 28: 933-7.

19 Sanderson JD, Moss MT, Tizard MLV, Hermon-Taylor J. Mycobacterium paratuberculosis DNA in Crohn's disease tissue. Gut 1992; 33: 890-6.

20 Fidler HM, Thurrell W, Johnson NMcI, Rook GAW, McFadden JJ. Specific detection of Mycobacterium paratuberculosis DNA associated with granulomatous paratuberculosis DNA associated with granul
tissue in Crohn's disease. Gut 1994; 35: 506-10.

21 Ibbotson JP, Fidler H, Chahal H, Mussaddeq Y, Allan RN, $\mathrm{McF}$ adden JJ. Detection by polymerase chain reaction of
Mycobacterium paratuberculosis-specific DNA in Crohn's disease tissues. Gut 1994; 35: A165.

22 Dell'Isola B, Poyart C, Goulet O, Mougenot JF, SadounJourno E, Brousse N, et al. Detection of Mycobacterium paratuberculosis by polymerase chain reaction in children with Crohn's disease. F Infect Dis 1994; 169: 449-51.

23 Wu SWP, Pao CC, Chan J. Lack of mycobacterial DNA in Crohn's disease tissue. Lancet 1991; 337: 174-5.

24 Rosenberg WMC, Bell JI, Jewell DP. Mycobacterium paratuberculosis DNA cannot be detected in Crohn's disease tissues. Gastroenterology 1991; 100: A611.

25 Quirke P, Dockey D, Taylor GR, Lewis FA, Hawkey P, Graham D, et al. Detection of Mycobacterium paratuberculosis in inflammatory bowel disease. Gut 1991; 32: A108.

26 Thorel M-F, Krichevsky M, Levy-Frebault VV. Numerical taxonomy of mycobactin-dependent mycobacteria, emended description of Mycobacterium avium, and description of Mycobacterium avium subsp avium subsp nov, Mycobacterium avium subsp paratuberculosis subsp nov, and Mycobacterium avium subsp silvaticum subsp nov, and Mycobacterium avium subsp silvaticum subsp

Eisenstein BI. The polymerase chain reaction. A new method of using molecular genetics for medical diagnosis. Engl

28 Erlich HA, Gelfand D, Sninsky JJ. Recent advances in the polymerase chain reaction. Science 1991; 252: 1643-51. 